\title{
Change in Work-Time Control and Work-Home Interference Among Swedish Working Men and Women: Findings from the SLOSH Cohort Study
}

\author{
Constanze Leineweber ${ }^{1}$ • Göran Kecklund ${ }^{1,2}$ • Petra Lindfors ${ }^{3}$. \\ Linda L. Magnusson Hanson ${ }^{1}$
}

Published online: 28 April 2016

(C) The Author(s) 2016. This article is published with open access at Springerlink.com

\begin{abstract}
Purpose The aim is to study the influence of change in worktime control (WTC) on work-home interference (WHI) while adjusting for other work-related factors, demographics, changes at work and WHI at baseline among women and men. An additional aim was to explore sex differences in the relation between change in WTC and WHI.

Methods The study included working participants of the Swedish Longitudinal Occupational Survey of Health (SLOSH) study of the third (2010) and fourth (2012) waves $(n=5440)$. Based on a seven-item index, four groups of WTC were formed: stable high (40\%), stable low (42\%), increasing ( $9 \%)$, or decreasing (9\%) WTC over the 2 years. WHI was measured by four items and individuals were categorised in whether suffering or not suffering of WHI. Sex-stratified logistic regression analyses with $95 \%$ confidence intervals (CI) were used to estimate the odds of experiencing WHI by change in WTC.

Results Controlling for demographics and work-related factors, women with stable low $(\mathrm{OR}=1.46 ; 95 \%$ CI 1.14-1.88) and women and men with decreasing WTC (women $\mathrm{OR}=1.99 ; 95 \%$ CI $1.38-2.85$; men $\mathrm{OR}=1.80 ; 95 \%$ CI 1.18-2.73) had higher odds of WHI than those with a stable high WTC. Additionally, adjusting for changes at work and
\end{abstract}

Constanze Leineweber

constanze.leineweber@su.se

1 Stress Research Institute, Stockholm University, SE-106 91 Stockholm, Sweden

2 Behavioural Science Institute, Radboud University, Nijmegen, The Netherlands

3 Department of Psychology, Stockholm University, Stockholm, Sweden
WHI at baseline did not alter the results substantially. Interaction analysis did not reveal any significant sex difference in the relation between WTC and WHI.

Conclusions For both women and men decreased and for women only, low control over working hours resulted in WHI also after adjusting for work-related factors and demographics.

Keywords Gender · Work-home interference · Work-family conflict $\cdot$ Work-time control

\section{Introduction}

Many employees experience difficulties in satisfactorily combining work and home demands, which may result in conflicts between these demands. In Sweden, more than $30 \%$ of all parents seldom or never experience balance between demands from the work and home spheres [1], with figures from other European countries being similar. This type of imbalance may be associated with short- and long-term stress reactions and has been related to negative health outcomes including e.g. suboptimal sleep quality [2], poor self-rated health [2] and sickness absence [3]. Indeed, the European Agency for Safety and Health at Work Research has identified poor work-life balance as one of the top emerging psychosocial risks and warn for the negative consequences for the work force [4]. Thus, an adequate balance between work and private demands is important not only for the individual but also for organisations that want healthy and productive employees.

For organisations, one possible measure to facilitate the compatibility of work and home demands is to increase work-time control (WTC) which can be defined as 'an employee's possibilities of control over the duration, position and distribution of his or her work time' [5]. Two 
factors of work-time control can be differentiated, i.e. 'control over daily hours' and 'control over time off' [6]. This employee-friendly flexibility is to be distinguished from employer-friendly flexibility [7], also labelled 'variability' in some papers [8], which refers to 'the need of employers to extend, modify, or reduce hours according to client or production needs' [5].

Flexible working hours may potentially have positive consequences for both employers and employees [9]. Today, organisations increasingly offer flexible work-time arrangements [10], e.g. staggered working hours, flexitime arrangement and work-time banking to increase employees' possibilities to successfully combine home and work demands [11]. As the possibility to influence working times directly relate to the planning of time off work, WTC should have a positive effect on the possibility to combine work and non-work demands and make it easier to give priority to social and family needs. Indeed, several studies have shown positive associations between possibilities to influence working time and perceived workhome interference (WHI). Investigating a sample of human service employees in Germany, Kattenbach et al. found that time-autonomy reduced exhaustion and work-non-work conflict [12]. A Dutch study reported that time-spatial flexibility, i.e. part-time work, flexitime and telework from home, affected work-life balance positively [7]. Still, another study found that control over work time moderated the relationship between working hours and work-family balance, i.e. among employees with longer working hours, work-life balance was lower for workers with low WTC but not among those with higher WTC [13]. A systematic review concludes that there is relatively strong support to consider WTC as a promising tool for the maintenance of employees' work-non-work balance [14]. However, this conclusion is based mainly on studies with cross-sectional designs, while longitudinal studies investigating the effects of WTC on WHI are scarce.

There are a number of factors which possibly could modify the relation between WTC and work-life balance. Having children living at home and marital status have been linked both to WTC [6] and WHI [15] and have also been shown to moderate the effect of schedule flexibility on WHI [16]. Also, socio-economic status, in terms of educational level, is clearly related to WTC [6], whereas findings regarding WHI are less consistent [15]. Still, it seems that, particularly among women, higher social position is associated with an increased risk for WHI [17]. Overtime and long working hours have been related to increased WTC [6] with several studies having confirmed that long working hours are associated with higher levels of WHI [18]. Finally, perceived control over work hours is strongly associated with job control in the demand- control model [19, 20], and work demands and work control are potential antecedents of WHI [21].

As regards women and men, it is unclear whether both groups benefit equally from having increased control over their working hours. It has been suggested that work-time flexibility may have adverse consequences for women's work-home balance, as women may end up engaging in more non-work responsibilities [22]. This may, in turn, result in an increased total workload for women. However, empirical support for this hypothesis is limited. Whereas one study found that flexible work hours were beneficial for men only [23], another found that alternative work time arrangements (i.e. flexible work hours, job-sharing, telecommuting) decreased women's work-life balance, while it had no influence on the work-life balance of men [22]. Yet, another study found that while women used their control over working hours to achieve a better work-life balance, men used flexible work schedules to increase their work commitment, thereby increasing their perceived work-family conflict [24]. Thus, existing findings are mixed and allow no clear conclusions concerning sex differences.

Moreover, results of WTC-related intervention studies have been mixed [25-27]. One intervention study of female nurses found positive changes for work-life balance, social support and job satisfaction after introducing self-scheduling [25]. However, another intervention study including female eldercare workers found no effects of increased WTC on work-life balance [27]. Yet, another intervention study found that changes in schedule control had similar positive effects on work-family conflict for men and women [26].

Taken together, further research is needed to delineate whether WTC will provide both women and men with adequate possibilities to combine work and private life demands and to clarify whether increased WTC is a good strategy for enhancing work life balance for both sexes.

This study aims to expand the understanding of the role of WTC for WHI by using an observational design with longitudinal data focusing on differences between women and men. Specifically, the study aimed at investigating how changes in WTC relate to WHI while also accounting for other workrelated factors, family characteristics and changes in work situation in both women and men.

\section{Methods}

\section{Study Sample}

The study population consisted of the participants of the Swedish Longitudinal Occupational Survey of Health (SLOSH) study, a longitudinal cohort survey with a focus on the association between work organisation, work environment and health. The SLOSH sample is drawn from respondents to 
the Swedish Work Environment Surveys (SWES) conducted biennially by Statistics Sweden. In 2006, SLOSH started with a first follow-up of SWES participants 2003. In 2008, SWES 2005 participants were added to the cohort, totalling a population of 18,915 individuals.

The participants are followed by means of a postal questionnaire in two versions, one for those currently in paid work, i.e. working for at least $30 \%$ of full time or a version for those not in paid work, i.e. those working less than $30 \%$ or who are permanently or temporarily outside the labour force. The current paper included participants, who responded to the questionnaire for those in paid work (including self-employed) both in 2010 (wave 3) and 2012 (wave 4) $(n=5569)$. Of the 9131 working participants in 2010, 2818 (30.9\%) did not answer any questionnaire in 2012. A further 745 (25.4\%) completed the questionnaire for non-working participants. After exclusion of participants with missing values on work-time control at any time, the sample size was reduced to 5440 participants. Slightly more women and participants in a higher socio-economic group completed the questionnaires for working individuals in both 2010 and 2012. There were no age differences between respondents and non-respondents. Informed consent was obtained from all individual participants included in the study. Both SLOSH and the present study have been approved by the Regional Research Ethics Board in Stockholm.

\section{Measures}

WHI was measured by an adapted version of a questionnaire developed by Fisher [28], which was designed to measure directions and domains of WHI. Four questions cover WHI (Cronbach's alpha 0.89). Response alternatives ranged from 1 ('not at all') to 5 ('nearly all the time'). Table 1 presents these questions and response frequencies. When at least three out of the four items were completed, a mean score was calculated. A mean of 3.5 or higher was considered to reflect WHI. This cut-off has satisfactory psychometric properties (specificity $=88 \%$, sensitivity $=77 \%$, kappa $=0.497$ ) when compared with a single-item question 'Do the demands placed on you at work interfere with your home and family life?' which was dichotomised according to the response options 'very often' or 'the whole time', and used as a validity index.

WTC was measured by an adapted six-item Swedish version of the seven-item index developed by Ala-Mursula [20]. The items cover influence over scheduling and aspects of flexi-time, breaks, short time leave, vacation and the possibility to do private errands during working time. Items were combined and the composite score re-categorised into five response categories ranging from $1=$ 'very little' to $5=$ 'very much' WTC on average. Cronbach's alpha was satisfying with a value of .88 in both 2010 and 2012. Four groups were constructed with regard to change in WTC (Table 2). Those who reported having 'quite a little' or very little control at both measurement times were considered to have stable low WTC $(n=2281,41.9 \%)$. Those who reported having WTC at least 'to some extent' at both measurement times were considered to have stable high WTC $(n=2202,40.5 \%)$. Further, those who reported very little or quite a little WTC at $\mathrm{t} 1$ but reported having WTC to at least 'some extent' at $\mathrm{t} 2$ were considered to have experienced an increase in WTC $(n=482,8.9 \%)$. Last, those who experienced WTC to some extent or more at t 1 and quite a little or less WTC at $\mathrm{t} 2$ were considered as reporting decreased WTC ( $n=475,8.7 \%)$.

Sex, obtained from register data linked to questionnaire responses by means of the unique ten-digit personal identification numbers in Sweden, was used as a stratifying variable. Marital status, having children living at home, socio-economic status, work demands and decision authority, shift work and weekly working hours measured in 2010 were considered as possible confounders. Marital status was obtained by a single question with response alternatives 'single' or 'married/cohabiting' coded. Having children living at home was measured by a single question 'Do you have any children living at home? Include children living with you at least half of the time.' and coded into yes and no. The socio-economic status was based on the Swedish socio-economic classification (SEI) which not only builds mainly on the occupation (as reported in the questionnaire) but also takes length of education into account [29]. We used six categories, i.e. unskilled manual workers (reference category) [1], skilled manual workers [2], assistant non-manual employees [3], intermediate non-manual employees [4], professionals and upper-level executives [5], self-employed [6] and others. Weekly working hours was measured by one item with eight response categories, ranging from $1=$ ' $<35 \mathrm{~h} /$ week' to $8=$ ' $>65 \mathrm{~h} /$ week'. In analyses, working hours were handled as a continuous variable. Job demands (five items) and decision authority (six items) were measured according to the demand-control model [30] and handled as continuous variables. Shift work was measured by a single item with nine response alternatives and recoded into six categories of shift work, covering daytime (forming the reference category), afternoon and evening work, shift work (two and three shift), roster work (which is defined as a more irregular type of shift work, e.g. common in the transport sector) and nonregulated working hours. A last alternative covered 'other work time'. Further, we considered whether changes at work during the study period (i.e. 2010-2012) would explain possible changes in WTC and WHI. A better job position may be associated with more WTC but may also (due to higher demands) be associated with more WHI. Thus, having been promoted during the past 2 years and having got a new manager during the past 2 years, as 
Table 1 Items for work-home interference (WHI) measured in 2012 and corresponding frequencies for women and men

\begin{tabular}{|c|c|c|c|c|c|c|c|c|c|c|}
\hline \multirow[t]{3}{*}{ Item } & \multicolumn{10}{|c|}{ Response alternative } \\
\hline & \multicolumn{2}{|l|}{ 'Not at all' } & \multicolumn{2}{|l|}{ 'Rarely' } & \multicolumn{2}{|c|}{ 'Sometimes' } & \multicolumn{2}{|l|}{ 'Often' } & \multicolumn{2}{|c|}{ 'Nearly all time' } \\
\hline & $\begin{array}{l}\text { Men, } n \\
(\%)\end{array}$ & $\begin{array}{l}\text { Women, } \\
n(\%)\end{array}$ & $\begin{array}{l}\text { Men, } n \\
(\%)\end{array}$ & $\begin{array}{l}\text { Women, } \\
n(\%)\end{array}$ & $\begin{array}{l}\text { Men, } n \\
(\%)\end{array}$ & $\begin{array}{l}\text { Women, } \\
n(\%)\end{array}$ & $\begin{array}{l}\text { Men, } n \\
(\%)\end{array}$ & $\begin{array}{l}\text { Women, } \\
n(\%)\end{array}$ & $\begin{array}{l}\text { Men, } n \\
(\%)\end{array}$ & $\begin{array}{l}\text { Women, } \\
n(\%)\end{array}$ \\
\hline $\begin{array}{l}\text { I come home from work too tired to } \\
\text { do things I would like to do. }\end{array}$ & $\begin{array}{l}165 \\
\quad(7.05)\end{array}$ & $\begin{array}{l}155 \\
\quad(5.10)\end{array}$ & $\begin{array}{l}512 \\
\quad(21.87)\end{array}$ & $\begin{array}{l}432 \\
\quad(14.21)\end{array}$ & $\begin{array}{l}1086 \\
\quad(46.39)\end{array}$ & $\begin{array}{l}1302 \\
\quad(42.81)\end{array}$ & $\begin{array}{l}496 \\
(21.19)\end{array}$ & $\begin{array}{l}874 \\
\quad(28.74)\end{array}$ & ${ }^{82}(3.50)$ & $\begin{array}{l}278 \\
(9.14)\end{array}$ \\
\hline $\begin{array}{l}\text { My job makes it difficult to } \\
\text { maintain the kind of personal life } \\
\text { I would like. }\end{array}$ & $\begin{array}{l}644 \\
\quad(27.50)\end{array}$ & $\begin{array}{l}887 \\
\quad(29.19)\end{array}$ & $\begin{array}{l}719 \\
\quad(30.70)\end{array}$ & $\begin{array}{l}746 \\
(24.55)\end{array}$ & $\begin{array}{l}627 \\
\quad(26.77)\end{array}$ & $\begin{array}{l}810 \\
\quad(26.65)\end{array}$ & $\begin{array}{l}286 \\
\quad(12.21)\end{array}$ & $\begin{array}{l}437 \\
\quad(14.38)\end{array}$ & $\begin{array}{l}66 \\
(2.82)\end{array}$ & $\begin{array}{l}159 \\
(5.23)\end{array}$ \\
\hline $\begin{array}{l}\text { I often neglect my personal needs } \\
\text { because of the demands of } \\
\text { my work. }\end{array}$ & $\begin{array}{l}518 \\
\quad(22.12)\end{array}$ & $\begin{array}{l}690 \\
(22.73)\end{array}$ & $\begin{array}{l}845 \\
\quad(36.08)\end{array}$ & $\begin{array}{l}942 \\
\quad(31.04)\end{array}$ & $\begin{array}{l}638 \\
\quad(27.24)\end{array}$ & $\begin{array}{l}830 \\
\quad(27.35)\end{array}$ & $\begin{array}{l}297 \\
\quad(12.68)\end{array}$ & $\begin{array}{l}430 \\
\quad(14.17)\end{array}$ & 44 & $\begin{array}{l}143 \\
(4.71)\end{array}$ \\
\hline $\begin{array}{l}\text { My personal life suffers because of } \\
\text { my work. }\end{array}$ & $\begin{array}{l}612 \\
\quad(26.13)\end{array}$ & $\begin{array}{l}834 \\
\quad(27.42)\end{array}$ & $\begin{array}{l}806 \\
(34.42)\end{array}$ & $\begin{array}{l}935 \\
\quad(30.74)\end{array}$ & $\begin{array}{l}636 \\
(27.16)\end{array}$ & $\begin{array}{l}829 \\
(27.25)\end{array}$ & $\begin{array}{l}238 \\
\quad(10.16)\end{array}$ & $\begin{array}{l}336 \\
\quad(11.05)\end{array}$ & $\begin{array}{l}50 \\
(2.13)\end{array}$ & $\begin{array}{l}108 \\
(3.55)\end{array}$ \\
\hline
\end{tabular}

measured in 2012, were included as potential explanatory variables (confounders) to changes in WTC.

\section{Statistical Analyses}

Chi-square and analyses of variance tests were performed to evaluate differences in covariates and WHI between WTC categories. Sex-stratified logistic regression analyses were used to estimate how change in WTC was associated with odds of experiencing WHI and $95 \%$ confidence intervals (CI). In the first step, we assessed the influence of change in WTC on WHI (Crude Model). In the next step (Model 1), we added demographic variables (i.e. marital status, having children living at home and socio-economic status) into the model. In the third step (Model 2), we added job demands, decision authority, working hours and shift work. In the fourth step (Model 3), we controlled for changes at work (i.e. promotion and new manager). Finally, in the last model (Model 4), we controlled for work home interference at baseline. To test if changes in WTC affected women and men differently, we calculated a synergy index with $95 \%$ confidence intervals as a measure of additive interaction [31]. All analyses were performed in SAS 9.3.

\section{Results}

Descriptive statistics are presented in Table 3. Slightly more women than men participated in the study. The mean age was about 49.6 years. Thirty-eight per cent of the participants worked between 36 and $40 \mathrm{~h}$, and $30 \%$ worked between 41 and $45 \mathrm{~h} /$ week. More than one quarter felt that they often or very often were too tired to do things they would like to do when they came home, but only around $13 \%$ felt that their personal life suffered because of their work (Table 1). WHI decrease over time; in 2010, about $23 \%$ experienced WHI, and in 2012, the percentage had decreased to $18.7 \%$. Generally, women reported WHI to a higher extent than men did. Also, clear differences in WHI between the four WTC groups were found.

Experiences of WTC were rather stable over the 2-year time $(r=0.78)$. Only about $9 \%$ experienced a decrease or increase in WTC. However, while men mostly reported stable high WTC, most of the women reported low WTC at both time points. Also, socio-economic status differed between WTC categories; around $67 \%$ of professionals and upperlevel executives, but only $14 \%$ of the unskilled workers reported having stable high WTC. Further, WTC was positively associated with a higher number of working hours, those with

Table 2 Number of respondents in four work-time control (WTC) categories (middle grey = stable low WTC, light grey =increasing WTC, dark grey $=$ decreasing WTC, white $=$ stable high WTC)

\begin{tabular}{|c|c|c|c|c|c|}
\hline $\begin{array}{l}2012 \rightarrow \\
2010 \downarrow\end{array}$ & Very little & Quite a little & To some extent & Quite a bit & Very much \\
\hline Very little & 720 & 307 & 54 & 9 & 1 \\
\hline Quite a little & 314 & 940 & 372 & 39 & 7 \\
\hline To some extent & 50 & 359 & 967 & 231 & 42 \\
\hline Quite a bit & 9 & 44 & 292 & 371 & 81 \\
\hline Very much & 5 & 8 & 31 & 78 & 109 \\
\hline
\end{tabular}


Table 3 Means and standard deviations (SD) of work-home interference (WHI) and covariates 2010, also subdivided by change in work-time control (WTC)

\begin{tabular}{|c|c|c|c|c|c|c|}
\hline & $\begin{array}{l}\text { All } \\
\text { Mean } \pm \mathrm{SD}, \\
n(\%)\end{array}$ & $\begin{array}{l}\text { Stable high WTC } \\
n=2202(40.5 \%) \\
\text { Mean } \pm \text { SD, } n(\%)\end{array}$ & $\begin{array}{l}\text { Stable low WTC } \\
n=2281(41.9 \%) \\
\text { Mean } \pm \text { SD, } n(\%)\end{array}$ & $\begin{array}{l}\text { Increased WTC } \\
n=482(8.9 \%) \\
\text { Mean } \pm \mathrm{SD}, n(\%)\end{array}$ & $\begin{array}{l}\text { Decreased WTC } \\
n=475(8.7 \%) \\
\text { Mean } \pm \text { SD, } n(\%)\end{array}$ & $\begin{array}{l}\text { Level of } \\
\text { significance* } \\
p\end{array}$ \\
\hline Age & $49.60 \pm 9.32$ & $49.17 \pm 9.62$ & $50.12 \pm 8.94$ & $49.89 \pm 9.48$ & $48.79 \pm 9.43$ & $<.0013$ \\
\hline Sex & & & & & & $<.0001$ \\
\hline Women & $3075(56.53)$ & $992(45.05)$ & $1563(68.52)$ & $263(54.56)$ & $257(54.11)$ & \\
\hline Men & $2365(43.47)$ & $1210(54.95)$ & $718(31.48)$ & $219(45.44)$ & $218(45.89)$ & \\
\hline Socio-economic status & & & & & & $<.0001$ \\
\hline $\begin{array}{l}\text { Unskilled manual } \\
\text { workers }\end{array}$ & $1155(21.70)$ & $103(4.80)$ & $506(22.56)$ & $80(17.06)$ & $65(13.95)$ & \\
\hline Skilled manual workers & $1648(30.96)$ & $164(7.64)$ & $534(23.84)$ & $82(17.48)$ & $82(17.60)$ & \\
\hline $\begin{array}{l}\text { Assistant non-manual } \\
\text { employees }\end{array}$ & $754(14.16)$ & $316(14.71)$ & $286(12.77)$ & $70(14.93)$ & $82(17.60)$ & \\
\hline $\begin{array}{l}\text { Intermediate non- } \\
\text { manual employees }\end{array}$ & $862(16.19)$ & $679(31.61)$ & $702(31.34)$ & $137(29.21)$ & $130(27.90)$ & \\
\hline $\begin{array}{l}\text { Professionals and upper- } \\
\text { level executives }\end{array}$ & $754(14.16)$ & $776(36.13)$ & $198(8.84)$ & $94(20.04)$ & $87(18.67)$ & \\
\hline $\begin{array}{l}\text { Self-employed and } \\
\text { others }\end{array}$ & $150(2.82)$ & $110(5.12)$ & $14(0.63)$ & $6(1.28)$ & $20(4.29)$ & \\
\hline Working hours & & & & & & $<.0001$ \\
\hline$<35 \mathrm{~h} /$ week & $861(16.12)$ & $273(12.60)$ & $442(19.75)$ & $59(12.37)$ & $87(19.00)$ & \\
\hline $36-40 \mathrm{~h} /$ week & $2055(38.48)$ & $644(29.72)$ & $1062(47.45)$ & $200(41.93)$ & $149(32.53)$ & \\
\hline 41-45 h/week & $1608(30.11)$ & $771(35.58)$ & $535(23.91)$ & $155(32.49)$ & $147(32.10)$ & \\
\hline $46-50 \mathrm{~h} /$ week & $562(10.52)$ & $325(15.00)$ & $139(6.21)$ & $44(9.22)$ & $54(11.79)$ & \\
\hline $51-55 \mathrm{~h} /$ week & $132(2.47)$ & $80(3.69)$ & $30(1.34)$ & $11(2.31)$ & $11(2.40)$ & \\
\hline 56-60 h/week & $65(1.22)$ & $44(2.03)$ & $13(0.58)$ & $4(0.84)$ & $4(0.87)$ & \\
\hline$>60 \mathrm{~h} /$ week & $57(1.07)$ & $30(1.38)$ & $17(0.76)$ & $4(0.84)$ & $6(1.31)$ & \\
\hline Shift work & & & & & & $<.0001$ \\
\hline Day time/evening work & $4166(77.54)$ & $957(45.38)$ & $1138(52.15)$ & 247 (53.35) & $239(52.88)$ & \\
\hline Night work & $100(1.86)$ & $2(0.09)$ & $91(4.05)$ & $3(0.63)$ & $4(0.85)$ & \\
\hline Shift work & $379(7.05)$ & $35(1.60)$ & $298(13.26)$ & $24(5.05)$ & $22(4.68)$ & \\
\hline Roster work & $324(6.03)$ & $31(1.42)$ & $243(10.81)$ & $29(6.11)$ & $21(4.47)$ & \\
\hline Non-regulated & $264(4.91)$ & $186(8.53)$ & $50(2.23)$ & $15(3.16)$ & $13(2.77)$ & \\
\hline Other & $140(2.61)$ & $1876(86.02)$ & $1501(66.80)$ & $392(82.53)$ & $397(84.47)$ & \\
\hline Got new manager & $2581(49.58)$ & $51(2.34)$ & $64(2.85)$ & $12(2.53)$ & $13(2.77)$ & $<.0001$ \\
\hline Changed position & & & & & & $<.0001$ \\
\hline Higher & $691(12.94)$ & $376(17.42)$ & $160(7.14)$ & $92(19.37)$ & $63(13.49)$ & \\
\hline Unchanged & $4478(83.84)$ & $1717(79.53)$ & $2019(90.13)$ & $362(76.21)$ & $380(81.37)$ & \\
\hline Lower & $172(3.22)$ & $66(3.06)$ & $61(2.72)$ & $21(4.42)$ & $24(5.14)$ & \\
\hline Experienced WHI 2010 & $1263(23.43)$ & $440(20.14)$ & $591(26.19)$ & $124(25.94)$ & $108(22.93)$ & $<.0001$ \\
\hline Experienced WHI 2012 & $1021(18.96)$ & $345(15.76)$ & $478(21.25)$ & $81(16.88)$ & $117(25.00)$ & $<.0001$ \\
\hline
\end{tabular}

${ }^{*} p$ value for GLM and chi-square test

the longest working hours reported most often stable high influence over their working time. Also, shift work (including night work and roster work) was associated with WTC, mostly reporting stable low WTC. Changes in working conditions were not related to major changes in WTC.

Tables 4 and 5 present results from the logistic regression analyses separately for women and men, with results being similar for both groups. In the unadjusted model, both women and men with decreased WTC had higher odds of experiencing WHI than those with stable high WTC. For women, also stable low WTC was related to WHI. After controlling for having children living at home, marital status and socioeconomic status (Model 1), both women and men with stable low or decreased WTC showed an excessed odds ratio of WHI. When additionally controlling for work demands, decision authority, working hours and shift work (Model 2), the odds ratio for decreased WTC increased somewhat for both women and men, but men with stable low WTC no longer showed an increased odds for WHI. Changes in work position or the work situation during the past 2 years (Model 3) did not explain the relationship between changes in work time control and WHI. Further controlling for baseline WHI did not change the results much (Model 4). Still, a decreasing WTC was related to higher odds for WHI for both women and men, and while men with stable low WTC had no increased odds for WHI, women with a stable low WTC reported an increased odds ratio for WHI also when controlling for baseline WHI. However, analyses of the additive interaction effect (in the fully adjusted model) between sex and change in WTC on WHI did not reveal any statistically significant difference 
Table 4 Results of the logistic regression models for women $(n=3075)$, presented in odds ratios with $95 \%$ confidence intervals of experiencing work-home interference (WHI)

\begin{tabular}{|c|c|c|c|c|c|c|}
\hline & $\begin{array}{l}\text { Cases } \\
\text { of WHI }\end{array}$ & $\begin{array}{l}\text { Model } 0 \\
\text { uncontrolled }\end{array}$ & $\begin{array}{l}\text { Model } 1 \\
\text { adjusted for } \\
\text { marital and } \\
\text { parental } \\
\text { status, and SES }\end{array}$ & $\begin{array}{l}\text { Model } 2 \\
\text { additionally } \\
\text { adjusted for job } \\
\text { demand and control, } \\
\text { weekly working hour } \\
\text { and shift work }\end{array}$ & $\begin{array}{l}\text { Model } 3 \\
\text { additionally } \\
\text { adjusted for } \\
\text { changes at work }^{\mathrm{a}}\end{array}$ & $\begin{array}{l}\text { Model } 4 \\
\text { additionally } \\
\text { adjusted for } \\
\text { baseline WHI }\end{array}$ \\
\hline \multicolumn{7}{|l|}{ Change in WTC } \\
\hline Stable high & $\begin{array}{l}138 \\
(17.8)\end{array}$ & Ref & Ref & Ref & Ref & Ref \\
\hline Stable low & $\begin{array}{l}354 \\
(22.6)\end{array}$ & $\begin{array}{l}1.42 \\
\quad(1.16-1.74)\end{array}$ & $\begin{array}{l}1.96 \\
\quad(1.57-2.47)\end{array}$ & $\begin{array}{l}1.46 \\
\quad(1.14-1.88)\end{array}$ & $\begin{array}{l}1.51 \\
\quad(1.16-1.96)\end{array}$ & $\begin{array}{l}1.50 \\
\quad(1.12-2.01)\end{array}$ \\
\hline Increase & 21 & $\begin{array}{l}0.95 \\
\quad(0.66-1.36)\end{array}$ & $\begin{array}{l}1.16 \\
\quad(0.79-1.68)\end{array}$ & $\begin{array}{l}0.85 \\
\quad(0.56-1.28)\end{array}$ & $\begin{array}{l}0.88 \\
\quad(0.58-1.34)\end{array}$ & $\begin{array}{l}0.84 \\
\quad(0.53-1.32)\end{array}$ \\
\hline Decrease & \multirow[t]{2}{*}{$\begin{array}{l}66 \\
(27.2)\end{array}$} & $\begin{array}{l}1.75 \\
\quad(1.27-2.42)\end{array}$ & $\begin{array}{l}2.07 \\
(1.48-2.90)\end{array}$ & $\begin{array}{l}1.99 \\
(1.38-2.85)\end{array}$ & $\begin{array}{l}2.08 \\
\quad(1.43-3.02)\end{array}$ & $\begin{array}{l}2.21 \\
(1.45-3.36)\end{array}$ \\
\hline R-square & & 0.007 & 0.027 & 0.112 & 0.114 & 0.243 \\
\hline
\end{tabular}

WTC work-time control, SES socio-economic status

${ }^{a}$ Changed work position and having got a new manager

in the relationship depending on sex. When analysing men and women together in the fully adjusted model (Model 4), both stable low ( $\mathrm{OR}=1.46 ; 95 \% \mathrm{CI} 1.16-1.84)$ and decreased WTC $(\mathrm{OR}=2.14 ; 95 \%$ CI 1.56-2.93) increased the odds for WHI.

\section{Discussion}

The present study, investigating the longitudinal associations between changes in WTC and WHI, showed that stable low WTC and decreased WTC were associated with higher odds of experiencing WHI. Hence, the results are in line with the findings of a systematic review showing that low WTC is associated with WHI [14] and agrees with results from a natural experiment, indicating a positive effect on work-family conflict after the implementation of unregulated working hours [32]. Still, the number of study participants in the intervention group was small $(n=325)$ and results not generalisable to the working population. Generally, the number of longitudinal studies investigating the effects of WTC is small [14], and there are only few studies investigating the effect of changes in WTC on WHI.

The second research question referred to sex differences, and no clear differences regarding the association between changes in WTC and WHI between women and men were found; the interaction effect was non-significant. Previous research has suggested that women in particular may benefit from control over work time due to sex differences in non-work demands [20,33]. Indeed, a Dutch study showed that time-spatial flexibility reduced working women's perceptions of WHI, but not men's [7]. Yet, work-time flexibility has also been suggested to have

Table 5 Results of the logistic regression models for men $(n=2365)$, presented in odds ratios with $95 \%$ confidence intervals of experiencing workhome interference (WHI)

\begin{tabular}{|c|c|c|c|c|c|}
\hline $\begin{array}{l}\text { Cases of WHI, } \\
N(\%)\end{array}$ & $\begin{array}{l}\text { Model } 0 \\
\text { uncontrolled }\end{array}$ & $\begin{array}{l}\text { Model } 1 \\
\text { adjusted for } \\
\text { marital and parental } \\
\text { status, and SES }\end{array}$ & $\begin{array}{l}\text { Model } 2 \\
\text { additionally } \\
\text { adjusted for job } \\
\text { demands and control, } \\
\text { weekly working hour } \\
\text { and shift work }\end{array}$ & $\begin{array}{l}\text { Model } 3 \\
\text { additionally } \\
\text { adjusted for changes } \\
\text { at work }{ }^{\mathrm{a}}\end{array}$ & $\begin{array}{l}\text { Model } 4 \\
\text { additionally } \\
\text { adjusted for } \\
\text { baseline WHI }\end{array}$ \\
\hline
\end{tabular}

\begin{tabular}{lllllll}
\hline Change in WTC & & & & & \\
Stable high & $128(14.0)$ & Ref & Ref & Ref & Ref & \multicolumn{1}{l}{ Ref } \\
Stable low & $131(16.5)$ & $1.21(0.94-1.56)$ & $1.36(1.00-1.83)$ & $1.15(0.81-1.64)$ & $1.11(0.76-1.60)$ & $1.19(0.79-1.80)$ \\
Increase & $23(12.8)$ & $1.23(0.83-1.81)$ & $1.38(0.92-2.07)$ & $1.26(0.81-1.95)$ & $1.38(0.88-2.16)$ & $1.35(0.80-2.27)$ \\
Decrease & $43(21.1)$ & $1.73(1.21-2.48)$ & $1.88(1.29-2.74)$ & $1.80(1.18-2.73)$ & $1.73(1.12-2.69)$ & $1.95(1.19-3.20)$ \\
R-square & & 0.004 & 0.010 & 0.096 & 0.095 & 0.232 \\
\hline
\end{tabular}

WTC work-time control, SES socio-economic status

${ }^{a}$ Changed work position and having got a new manager 
negative consequences for women, in the way that women may end up engaging in more non-work responsibilities, rather than using the increased time control to fully recover and reduce strain outcomes [22]. Indeed, a report from the European Commission suggests that flexibility in the length of working time seems to have some adverse effects on gender equality since it increases part-time work among women [11]. In contrast to these suggestions, we could not find any statistically significant difference between men and women on the relationship between change in WTC and WHI. Thus, our results indicate that, at least within a Swedish context, both men and women may benefit from increased control over their working hours. However, in contrast to e.g. the Netherlands, Sweden is a country with a high number of full-time working women and which guarantees subsidised day care to all children above 1 year of age. Another explanation of our findings may relate to the fact that Sweden is a country with high equality between women and men, with increasing number of men sharing the responsibility for household demands.

Additionally, our results suggest that a decrease in WTC has a stronger effect on WHI than a stable low WTC. Indeed, individuals having a low control over their working time may arrange their lives accordingly, whereas those who had a greater influence on their working time but experienced a decrease in control may experience some difficulties before making these arrangements.

Another interesting finding was that WTC seems to be generally stable; less than one fifth reported a change in WTC. This might indicate that WTC is strongly associated with educational level and occupation/profession, and thus factors not changing dramatically during working life. Also, changes in relation to work (new position and/or new manager) were unrelated to changes in WTC, indicating that changes primarily happen within the same socio-economic group and/ or occupation. Indeed, most of the study participants had the same job position at both times of measurement ( $84 \%)$. Also, promotions are often related to increased demands, which may reduce possible positive effects of more WTC. Lastly, WTC is highly inherent to the occupation and depends largely on organisational policies which, in turn, diminishes the influence of the new manager. A high number of employees reported little influence over their working hours. Also, women reported considerably more often than men a stable low WTC (51 vs. $30 \%$ ). This is in line with findings reported by the European Commission showing that women are generally more likely to have fixed finishing and starting times than men (68\% of women vs. $58 \%$ of men) [34]. This difference might be partly explained by the fact that women more often work in the public sector and in jobs which require more or less fixed working hours, as in healthcare or education [28].

Also, the perception of WTC and its consequences may be influenced by both need for WTC and opportunities for social support. For individuals with a low need for WTC, e.g. no need to adapt work time to the scheduling of child-care, low WTC is a problem to a much lesser extent than for a single parent with small children and no social support. Unfortunately, we had no possibility to control for social support outside work, although this could be a possible confounder influencing the relationship between changes in WTC and WHI.

Our study adds to the knowledge on the potential effects of changes in WTC on WHI. However, some shortcomings should be acknowledged. First, the rather small groups of workers who report increased or decreased control over their working hours limit statistical power. Yet, the results indicated that decreasing and stable low WTC might have an influence on WHI. Second, despite the longitudinal study design, no firm conclusions about causality can be drawn. Other changes at the workplace may foster the contemporary improvement in WTC and WHI. Although we adjusted for a change in position or getting a new manager, we cannot exclude that other important changes have influenced the results. Still, controlling for a number of possible confounders did not alter the results much, and so there is reason to consider an increased WTC as a promising tool for improving employees work-life balance.

Of course, the 2-year time lag can be considered a weakness. Two years may be too long to detect effects especially as work-family conflict may arise on a day-to-day level. Still, the 2-year time lag is similar to what other large occupational cohort studies (e.g. the Finish Public Sector study) use. Also, analyses revealed some differences between those who had missing data at one or several study variables and those who had full information on all study variables. Those with missing data on one or several study variables were in average younger, had lower socio-economic position and worked more often shift-work $(p<0.01)$. However, no differences in sex or weekly working hours were observed. Also, participants with low WTC at baseline did answer the follow-up questionnaire to the same extent as participants with high baseline WTC. The study group was relatively old (mean age was 49 years), which suggests that employees with small children are underrepresented in the sample. This might also explain the general decrease in WHI over the 2 years. As a consequence, the prevalence of WHI might have been underestimated. Additionally, relying solely on self-reports may involve social desirability and the ordering and wording of items may bias participants' ratings. Using only questionnaire data may also result in common method bias. The feeling of being able to influence work-time aspects may be contaminated by other work-related variables, e.g. the relation to the supervisor. Also, individuals who are satisfied with their working hours might report more WTC than the unsatisfied, although they have objectively the same control over working time. However, a comparison between surveyreported ratings of employee control and qualitative data on 
existing practices supports self-reports as a valid measure [35, 36]. Furthermore, the construct of WHI is adequately assessed through self-reports in questionnaires, and objective measures are not available. Supported by finding by Nijp [14] who reported moderately strong evidence that WTC promotes better work-life balance, we are confident that our results are not explained by reporting issues. Further, we studied only availability of WTC and not the actual use of it. Moreover, we used a composite measure of WTC which covers rather two different aspects of flexibility, i.e. control over daily hours and control over time off [6]. Future research should investigate the impact of the different sub-dimensions of WTC and their impact on different outcomes. For example, the possibility to take breaks when wanted or needed may be related primarily to recovery, whereas the possibility to adjust starting and finishing times may be more strongly related to work-life balance.

In summary, our findings based on a large representative cohort of Swedish employees indicate that low and decreased control over working hours may have negative effects on WHI for both women and men. The practical implication of this observation is that increased WTC can reduce the conflict between work and non-work life, which in turn could improve well-being and decrease work stress-related health problems.

Contributorship Statement CL and GK formulated the study design. $\mathrm{CL}$ carried out the statistical analyses and wrote the first and successive drafts of the paper. LMH advised on the analyses. All authors interpreted the results, revised the text for important intellectual content and approved the final draft of the report.

\section{Compliance with Ethical Standards}

Conflict of Interest The authors declare that they have no conflict of interest.

Funding This study was supported by the Swedish Research Council for Health, Working life, and Welfare (FORTE, grant no. 2013-0448). This work was also supported by the Swedish Council for Working Life and Social Research (FAS, grants no. 2004-2021, 2005-0734, 20091077), the Swedish Research Council (VR, grant no. 2009-6192), NordForsk, the Nordic Program on Health and Welfare, and partly funded by the Stockholm Stress Center, a FORTE Centre of Excellence (FORTE, grant no. 2009-1758). The funding sources were involved neither in the conduct of the research nor in the preparation of the article.

Open Access This article is distributed under the terms of the Creative Commons Attribution 4.0 International License (http:// creativecommons.org/licenses/by/4.0/), which permits unrestricted use, distribution, and reproduction in any medium, provided you give appropriate credit to the original author(s) and the source, provide a link to the Creative Commons license, and indicate if changes were made.

\section{References}

1. Nylin A-K. En av tre föräldrar upplever inte balans i livet. Välfärd. 2008;3:22-3.
2. Nylen L, Melin B, Laflamme L. Interference between work and outside-work demands relative to health: unwinding possibilities among full-time and part-time employees. Int J Behav Med. 2007;14(4):229-36.

3. Voss M, Josephson M, Stark S, et al. The influence of household work and of having children on sickness absence among publicly employed women in Sweden. Scand J Public Health. 2008;36(6): 564-72.

4. Brun E, Milczarek M, Roskams N, et al. Expert forecast on emerging psychosocial risks related to occupational safety and health. Luxembourg: Office for Official Publications of the European Communities 2007.

5. Härmä M. Workhours in relation to work stress, recovery and health. Scand J Work Environ Health. 2006;32:502-14. doi:10. 5271/sjweh.1055.

6. Albrecht SC, Kecklund G, Tucker P, Leineweber C. Investigating the factorial structure and availability of work time control in a representative sample of the Swedish working population. Scand J Public Health. 2015. doi:10.1177/1403494815618854.

7. Peters P, den Dulk L, van der Lippe T. The effects of time-spatial flexibility and new working conditions on employees' work-life balance: the Dutch case. Community Work Fam. 2009;12(3):270 97.

8. Costa G, Sartori S, Akerstedt T. Influence of flexibility and variability of working hours on health and well-being. Chronobiol Int. 2006;23(6):1125-37. doi:10.1080/07420520601087491.

9. Rapoport R, Bailyn L, Fletcher JK, Pruitt BH. Beyond work family balance: advancing gender equity and workplace performance. London: Jossey Bass; 2002.

10. Beckers DG, Kompier MA, Kecklund G, Harma M. Worktime control: theoretical conceptualization, current empirical knowledge, and research agenda. Scand J Work Environ Health. 2012;38(4): 291-7. doi:10.5271/sjweh.3308.

11. Plantenga J, Remery C. Flexible working time arrangements and gender equality. A comparative review of 30 European countries. Luxembourg: Publications Office of the European Union; 2009.

12. Kattenbach R, Demerouti E, Nachreiner F. Flexible working times. effects on employees' exhaustion, work-nonwork conflict and job performance. Career Dev Int. 2010;15(3):279-95.

13. Valcour M. Work-based resources as moderators of the relationship between work hours and satisfaction with work-family balance. J Appl Psychol. 2007;92(6):1512-23. doi:10.1037/0021-9010.92.6. 1512.

14. Nijp HH, Beckers DG, Geurts SA, Tucker P, Kompier MA. Systematic review on the association between employee worktime control and work-non-work balance, health and well-being, and job-related outcomes. Scand J Work Environ Health. 2012;38(4): 299-313. doi:10.5271/sjweh.3307.

15. Geurts SAE, Demerouti E. Work/non-work interface: a review of theories and findings. In: Schabracq M, Winnubst JAM, Cooper CL, editors. The handbook of work and health psychology. 2nd ed. Chichester: J. Wiley \& Sons, Ltd.; 2003. p. 279-312.

16. Michel JS, Kotrba LM, Mitchelson JK, Clark MA, Baltes BB. Antecedents of work-family conflict: a meta-analytic review. J Organ Behav. 2011;32:689-725. doi:10.1002/job.695.

17. Lahelma E, Winter $T$, Martikainen $P$, Rahkonen O. Työn ja perheen väliset ristiriidat ja niiden taustatekijät naisilla ja miehillä (Workfamily conflicts and their social background factors for women and men). Työ ja ihminen. 2005;19(1):34-48.

18. Grzywacz JG, Marks NF. Reconceptualizing the work-family interface: an ecological perspective on the correlates of positive and negative spillover between work and family. J Occup Health Psychol. 2000;5(1):111-26.

19. Karasek R, Theorell T. Healthy work - stress, productivity and the reconstruction of working life. New York: Basic Books; 1990. 
20. Ala-Mursula L, Vahtera J, Kivimaki M, Kevin MV, Pentti J. Employee control over working times: associations with subjective health and sickness absences. J Epidemiol Community Health. 2002;56(4):272-8.

21. Byron K. A meta-analytic review of work-family conflict and its antecedents. J Vocat Behav. 2005;67(2):169-98.

22. Hammer LB, Neal MB, Newsom JT, Brockwood KJ, Colton CL. A longitudinal study of the effects of dual-earner couples' utilization of family-friendly workplace supports on work and family outcomes. J Appl Psychol. 2005;90:799-810.

23. Jansen NWH, Kant I, Nijhuis FJN, Swaen GMH, Kristensen TS. Impact of worktime arrangements on work-home interference among Dutch employees. Scand J Work Envrion Health. 2004;30(2):139-49.

24. Hofäcker D, König S. Flexibility and work-life conflict in times of crisis: a gender perspective. Int J Sociol Soc Policy. 2013;33(9/10): 613-35.

25. Pryce J, Albertsen K, Nielsen K. Evaluation of an open-rota system in a Danish psychiatric hospital: a mechanism for improving job satisfaction and work-life balance. J Nurs Manag. 2006;14(4):2828. doi:10.1111/j.1365-2934.2006.00617.x.

26. Kelly EL, Moen P, Tranby E. Changing workplaces to reduce workfamily conflict: schedule control in a white-collar organization. Am Sociol Rev. 2011;76(2):265-90. doi:10.1177/0003122411400056.

27. Nabe-Nielsen K, Garde AH, Diderichsen F. The effect of work-time influence on health and well-being: a quasi-experimental intervention study among eldercare workers. Int Arch Occup Environ Health. 2011;84(6):683-95. doi:10.1007/s00420-011-0625-8.
28. Fisher GG, Bulger CA, Smith CS. Beyond work and family: a measure of work/nonwork interference and enhancement. J Occup Health Psychol. 2009;14(4):441-56.

29. Statistics Sweden. Socioeconomisk indelning (SEI) [Socioeconimic classification]. Stockholm 1982.

30. Theorell T. The demand-control-support model for studying health in relation to the work environment - an interactive model. In: OrthGomér K, Schneiderman N, editors. Behavioral medicine approaches to cardiovascular disease prevention. Mahwah, NJ: Lawrence Erlbaum Associates; 1996. p. 69-85.

31. Andersson T, Alfredsson L, Kallberg H, Zdravkovic S, Ahlbom A. Calculating measures of biological interaction. Eur J Epidemiol. 2005;20(7):575-9.

32. Moen P, Kelly EL, Hill R. Does enhancing work-time control and flexibility reduce turnover? A naturally occurring experiment. Soc Probl. 2011;58(1):69-98.

33. Ala-Mursula L, Vahtera J, Pentti J, Kivimaki M. Effect of employee worktime control on health: a prospective cohort study. Occup Environ Med. 2004;61(3):254-61.

34. Nabe-Nielsen K, Garde AH, Albertsen K, Diderichsen F. The moderating effect of work-time influence on the effect of shift work: a prospective cohort study. Int Arch Occup Environ Health. 2011;84(5):551-9. doi:10.1007/s00420-010-0592-5.

35. Thomas LT, Ganster DC. Impact of family-supportive work variables on work-family conflict and strain: a control perspective. J Appl Psychol. 1995;80:6-15.

36. Ala-Mursula L. Employee worktime control and health Oulu: University of Oulu; 2006. 